\title{
IDENTIFIKASI KANDUNGAN KIMIA GOLONGAN SENYAWA DAUN POHON KAPUK (Ceiba pentandra L.) SEBAGAI OBAT TRADISIONAL
}

\author{
SUAIBATUL ASLAMIAH \& HARYADI \\ Dosen Fakultas Pertanian dan Kehutanan Universitas Muhammadiyah Palangkaraya
}

\begin{abstract}
Kapok tree is used as an antidote for post-birth mother and for the treatment of deep wounds. Based benefit cottonwood tree researchers interested in knowing the content of the active compounds in the leaves of cottonwood with an experimental method for identifying active compounds. The method used is an experiment to identify active compounds what is contained in the leaves of cottonwood trees.

Research conducted at the Faculty of Health Sciences at the University of Muhammadiyah Palangkaraya assay ethanol -soluble extract the same method as the determination of water content i.e. gravimetric method. The solvent used is $95 \%$ ethanol, and then evaporated. Methods used in the determination of cider levels equal to the determination of levels of sari that is soluble in water that is a method of gravimetric. The solvent used for the solution penyari i.e. $95 \%$ ethanol is then evaporated over a water bath until dry and heated in an oven with a temperature of $1050 \mathrm{C}$ to constant weight. Levels of ethanol -soluble extract obtained results, namely $4.8 \%$

Test results can Fitokomia in tannin (fe Cltambah egg albumin) negative, positive drgendroff alkoloid, Alkaloids meyer negative, negative Alkoloid Bouchardat, saponin HHCL2N positive, negative Flavonoides and steroids and Terp Steroid and Terpenoid (acetate acid concentrated sulfuric acid anhidtrat positive.
\end{abstract}

Keywords : compound kapok tree, traditional medicine

\begin{abstract}
ABSTRAK
Pohon Kapuk yang pohonnya digunakan sebagai obat penawar racun bagi ibu pasca melahirkan dan untuk pengobatan luka dalam. Berdasarkan manfaat pohon kapuk peneliti tertarik mengetahui kandungan senyawa aktif pada daun kapuk dengan metode eksperimen untuk mengidentifikasikan senyawa aktif. Metode yang digunakan adalah eksperimen untuk mengidentifikasikan senyawa-senyawa aktif apa saja yang terdapat pada daun pohon kapuk.

Penelitian dilaksanakan di Fakultas IImu Kesehatan Universitas Muhammadiyah Palangkaraya pada penetapan kadar sari yang larut dalam etanol metode yang sama seperti penetapan kadar air yaitu metode gravimetric. Pelarut yang digunakan yaitu etanol $95 \%$, kemudian diuapkan. metode yang digunakan dalam penetapan kadar sari sama dengan penetapan kadar sari yang larut dalam air yaitu metode gravimetri. Pelarut yang digunakan untuk larutan penyari yaitu etanol $95 \%$. Kemudian diuapkan di atas penangas air hingga kering dan dipanaskan di dalam oven dengan suhu $105^{\circ} \mathrm{C}$ hingga bobot konstan. Kadar sari yang larut dalam etanol diperoleh hasil yaitu 4,8\%.

Hasil Uji Fitokomia di dapat tannin(fe Cltambah albumin telur) negatif, Alkoloid drgendroff positif, Alkaloid meyer negative,AlkoloidBouchardat Negatif, Saponin $\mathrm{HHCL}_{2} \mathrm{~N}$ positif, Flavonoid negatif,dan Steroid dan TerpSteroid dan Terpenoid ( asam aseta anhidtrat asam sulfat pekat positif
\end{abstract}

Kata kunci: senyawa pohon kapuk, obat tradisional 


\section{PENDAHULUAN}

Manusia sangat mengandalkan lingkungan sekitarnya untuk memenuhi kebutuhannya sehingga kekayaan alam sangat bermanfaat, akan tetapi belum sepenuhnya dikembangkan. Seiring dengan pesatnya kemajuan ilmu pengetahuan, para ahli obatobatan telah mengangkat pengobatan tradisional ke fenomena ilmiah, sehingga cukup banyak tumbuhan berkhasiat obat di lingkungan kita yang dapat digunakan sebagai obat. Di Indonesia telah lama mengenal dan menggunakan tanaman berkhasiat obat sebagai salah satu upaya dalam menanggulangi masalah kesehatan. Pengetahuan tentang tanaman berkhasiat dan digunakan sebagai obat berdasarkan pada pengalaman yang secara turun temurun telah diwariskan. Pengertian digunakan sebagai obat meliputi semua cara penggunaan yang berdampak fisikokimia seperti diminum, ditempel, untuk cuci, untuk mandi, dan dihirup (Tanaman Obat Indonesia, Jilid 1).

Bangsa Indonesia yang terdiri dari berbagai suku dan bangsa, memiliki keanekaragaman obat tradisional yang dibuat dari bahan-bahan alam. Bumi Indonesia yang dianugerahi keanekaragaman hayati tersebut, memiliki lebih dari 30.000 spesies tanaman dan 940 spesies diantaranya diketahui berkhasiat sebagai obat atau digunakan sebagai bahan obat (Puslitbangtri, 1992).

Penggunaan tanaman sebagai obat, sangat berkaitan dengan kandungan kimia yang terdapat dalam tanaman tersebut terutama zat bioaktif dalam tanaman. Senyawa bioaktif yang terdapat dalam tanaman atau tumbuhan biasanya merupakan golongan senyawa metabolit sekunder seperti golongan alkaloid. flavonoid, tanindan saponin

Salah satu kawasan yang banyak menyimpan keanekaragaman hayati untuk plasma nutfah tanaman obat adalah Kalimantan Tengah (Balai Pengkajian Teknologi Pertanian Kalimantan Tengah). Salah satu tanaman yang masyarakat Kalimantan Tengah gunakan sebagai obat tradisional adalah dauk pohon kapuk (Ceiba pentandra L.) atau masyarakat setempat kenal dengan nama tanaman sambung nyawa. Di Kalimantan Tengah masyarakat menggunakan daun dauk pohon kapuk (Ceiba pentandra L.)sebagai obat tradisional. Menurut sumber yaitu beberapa masyarakat Kabupaten Barito Timur dan beberapa masyarakat daerah jalan Cempaka Palangkaraya, daun tanaman dauk pohon kapuk (Ceiba pentandra L.)digunakan sebagai obat penawar racun bagi ibu pasca melahirkan dan untuk pengobatan luka dalam.

Berdasarkan latar belakang $\mathrm{di}$ atas peneliti tertarik untuk melakukan penelitian pada daun pohon kapuk kapuk (ceiba pentandra L). Apakah akar tanaman daun pohon kapuk (Ceiba pentandra L.). juga dapat digunakan sebagai obat seperti daunya yang digunakan untuk pengobatan. Maka peneliti melakukan penelitian dengan judul "Skrining Fitokimia Kandungan Senyawa Pada daun tanaman dauk pohon kapuk (ceiba pentandra L.) Sebagai Obat Tradisional”. 


\section{Rumusan Masalah}

Berdasarkan latar belakang yang diuraikan di atas, maka rumusan masalah pada penelitian ini adalah apakah akar tanaman daun pohon kapuk (Ceiba pentandra L.) terdapat golongan senyawa berkhasiat untuk pengobatan?

\section{Batasan Masalah}

Untuk menghindari perluasan masalah, maka Peneliti memberi batasan masalah sebagai berikut:

1. Sampel yang digunakan dalam penelitian yaitu akar tanaman daun pohon kapuk (Ceiba pentandra L.)Yang diambil di sekitar jalan Cempaka, Palangkaraya.

2. Golongan senyawa yang diidentifikasi yaitu alkaloid, flavonoid, saponin, dan tanin.

\section{Tujuan Penelitian}

Penelitian ini bertujuan untuk mengetahui kandungan senyawa kimia yang terkandung dalam akar tanaman daun pohon kapuk (Ceiba pentandra L.)sehingga dapat menambahkan informasi dalam penggunaan obat tradisional di Kalimantan Tengah.

\section{Manfaat Penelitian}

1. Sebagai penambah wawasan dan ilmu pengetahuan cara meneliti dan mengidentifikasi kandungan senyawa pada tanaman atau tumbuhan yang digunakan masyarakat sebagai obat tradisional.

2. Memberikan informasi tambahan kepada masyarakat tentang kandungan senyawa dan manfaat dari akar tanaman daun pohon kapuk (ceiba pentandra L) dapat digunakan untuk pengobatan tradisional.

\section{METODE PENELITIAN}

\section{Jenis Penelitian}

Penelitian ini merupakan penelitian eksperimen karena adanya perlakuan yang diberikan terhadap objek penelitian.

\section{Waktu dan Tempat}

Penelitian tentang "Identifikasi Fitokimia Kandungan Golongan Senyawa yang Terdapat pada daun kapuk sebagai Obat Tradisional' ini dilaksanakan mulai tanggal 15 Juli sampai dengan tanggal 30 september 2014 di laboratorium Fakultas IImu Kesehatan Universitas Muhammadiyah Palangkaraya.

\section{Alat dan Bahan}

1. Alat

Alat yang digunakan, antara lain : Blender, pisau, cawan porselin, kaca arloji, tabung reaksi, gelas ukur, timbangan, beker glass, corong pisah, kertas saring, pipet tetes, pipet volume, erlenmeyer, dan toples.

2. Bahan

Bahan-bahan yang digunakan untuk penelitian ini yaitu simplisia tumbuhan yang dalam keadaan kering, berupa Daun kapuk serta bahan-bahan kimia seperti : Aquades, $\mathrm{FeCl} 3$, Etanol $95 \%$, HCL Pekat, HCL 2N, Serbuk Magnesium, Bourchardat LP, Dragendroff LP, Mayer LP, Asam Asetat Anhidrat, Asam Sulfat Pekat dan Kloroform.

\section{Prosedur Penelitian}

\section{Pemilihan Simplisia}

Daun kapuk yang dipilih dalam penelitian ini adalah daun kapuk yang berada di wilayah kota Palangkaraya, Provinsi Kalimantan Tengah.

2. Pengambilan Simplisia 
Tanaman daun kapuk yang akan dijadikan sampel pada penelitian ini adalah bagian batang yang sudah cukup umur dengan warna cokelat pada batang lebih dominan dibanding dengan warna hijau. Cara pengambilan hanya dengan memotong bagian daun kapuk mulai dari pangkal batang hingga ujung batang.

\section{Pembuatan Simplisia}

Sebelum dijemur, simplisia (daun kapuk) dipisahkan dari daunnya. Kemudian di cuci menggunakan air, tujuan pencucian simplisia dilakukan untuk membersihkan kotoran yang melekat pada daun kapuk. Selanjutnya, daun kapuk dibagi menjadi 3 (tiga) bagian, tujuannya ketika dilakukan proses pengeringan sampel dapat kering secara merata. Kemudian, sampel dijemur di bawah sinar matahari langsung selama 3 (tiga) hari. Tujuan dari proses pengeringan untuk mendapatkan simplisia yang kering dan saat dihaluskan serta digunakan dalam penelitian tidak terlalu banyak memiliki kandungan air, setelah kering dihaluskan menggunakan mesin blender.

\section{Analisa Laboratorium}

Simplisia yang telah dikumpulkan dari pohon kapuk berupa daun kemudian dilakukan uji pendahuluan yang meliputi, penetapan susut pengeringan, penetapan sari yang larut dalam air dan penetapan sari yang larut dalam etanol. Dilanjutkan dengan identifikasi fitokimia menggunakan pereaksi yang sesuai.

a. Uji Pendahuluan

1). Penetapan Susut pengeringan (dalam buku Materia Medika Indonesia Jilid V, 1989).
Oven cawan porselin selama 15 menit, dinginkan dalam desikator selama 15 menit, kemudian timbang dan lakukan hingga bobot cawan konstan, timbang sampel 2 gram, lalu timbang sampel + cawan porselin, oven cawan dan sampel selama 3 jam dengan suhu $105^{\circ} \mathrm{C}$, lalu dinginkan dalam desikator dan ditimbang. Oven kembali hingga bobot tetap dan hitung dengan rumus penetapan susut pengeringan

$\frac{(\text { berat cawan }+ \text { sampel })-(\text { berat cawan }+ \text { sampel ker ing })}{(\text { berat cawan }+ \text { sampel })-\text { (erat cawan }} \times 100 \%$

2). Penetapan Kadar Sari yang larut dalam air (dalam buku Materia Medika Indonesia Jilid V, 1989).

Ditimbang 5 gram sampel, lalu di maserasi dengan $100 \mathrm{ml}$ air kloroform P, masukkan ke dalam wadah tertutup sambil berkali-kali di kocok selama 6 jam pertama, lalu kemudian dibiarkan selama 18 jam, saring dan uapkan $20 \mathrm{ml}$ filtrat hingga kering dalam cawan yang telah ditimbang, masukkan sisa filtrat ke dalam oven $105^{\circ} \mathrm{C}$ hingga bobot tetap dan hitung dengan rumus Penetapan kadar sari

Berat Ekstrak / Sari $=\frac{\text { Berat Ekstrak }}{\text { Berat Serbuk }} \times 100 \%$

3). Penetapan Kadar Sari yang Larut dalam etanol (dalam buku Materia Medika Indonesia Jilid V, 1989).

Ditimbang 5 gram sampel, lalu maserasi dengan $100 \mathrm{ml}$ etanol (95\%), masukkan ke dalam wadah tertutup sambil berkali-kali di kocok selama 6 jam pertama, lalu kemudian dibiarkan selama 18 jam. Saring dan uapkan $20 \mathrm{ml}$ filtrat hingga kering dalam cawan yang telah ditimbang masukkan 
sisa filtrat ke dalam oven $105^{\circ} \mathrm{C}$ hingga bobot tetap dan hitung dengan rumus :

Berat Ekstrak / Sari $=\frac{\text { Berat Ekstrak }}{\text { Berat Serbuk }} \times 100 \%$

a. Identifikasi Zat Kimia

1) Identifikasi Polifenol

Ditimbang ekstrak kental 0,5 gram, panaskan dengan $50 \mathrm{ml}$ air suling kemudian dipanaskan di atas penangas air selama 30 menit sambil diaduk sampai mendidih. Diamkan beberapa menit, saring larutan tersebut. Ambil filtrat 5 tetes masukkan ke dalam tabung reaksi. Reaksikan dengan larutan $\mathrm{FeCl} 3$ (2 tetes),jika larutan menunjukkan warna hitam hingga kebiruan maka positif adanya tanin kemudian lanjutkan kembali pengujian dengan menggunakan gelatin atau albumin. Jika terdapat endapan, maka positif tanin (Materia Medika Indonesia Jilid V, 1989).

2) Identifikasi Damar yang Pahit

Ditimbang ekstrak kental sampel sebanyak 0,5 gram, lalu tambahkan $1 \mathrm{ml}$ asam klorida dan $9 \mathrm{ml}$ air suling dan dipanaskan selama 2 menit. Kemudian, dinginkan dan disaring. Hasil uji dinyatakan positif apabila dengan :

a) 3 tetes sampel lalu ditambahkan 2 tetes pereaksi Dragendroff terbentuk endapan merah hingga jingga.

b) 3 tetes sampel lalu ditambahkan 2 tetes pereaksi Meyer terbentuk endapan putih kekuningan.

c) 3 tetes sampel ditambahkan 2 tetes pereaksi Bouchardat terbentuk endapan cokelat (Materia Medika Indonesia Jilid V, 1989).

3) Identifikasi Flavonoid
Sebanyak $1 \mathrm{ml}$ ekstrak cair ditambahkan dengan 1 gram serbuk Mg dan beberapa HCL pekat. Jika terjadi warna merah jingga sampai merah ungu, menunjukkan adanya flavonoid. (Materia Medika Indonesia Jilid V, 1989).

4) Identifikasi Saponin

Diambil ekstrak cair sampel sebanyak $1 \mathrm{ml}$, lalu diencerkan dengan $10 \mathrm{ml}$ air suling kemudian kocok kuat-kuat selama 10 detik. Apabila terbentuk buih mantap selama tidak kurang dari 10 menit, setinggi $1 \mathrm{~cm}$ sampai $10 \mathrm{~cm}$, dan pada penambahan 1 tetes asam klorida $2 \mathrm{~N}$ buih tidak hilang maka sampel positif mengandung saponin (Materia Medika Indonesia Jilid V, 1989).

5) Identifikasi Hidrat Arang

15 Diambil ekstrak kental sampel sebanyak 0,5 gram lalu tambahkan 2 tetes asam asetat anhidrat dan 1 tetes asam sulfat (H2SO4) pekat, jika menunjukkan warna ungu atau merah kemudian berubah menjadi biru hijau maka positif terdapat steroid dan terpenoid (Harbone. J. B, 1987).

\section{HASIL DAN PEMBAHASAN}

\section{Uji Pendahuluan}

Berdasarkan penelitian yang dilakukan pada uji pendahuluan dengan berbagai metode seperti gravimetri dan reaksi kimia diperoleh hasil uji pengukuran kadar air, penetapan kadar sari yang larut dalam air, dan penetapan kadar sari yang larut dalam ethanol.

Pada penetapan susut pengeringan yang digunakan yaitu metode gravimetri, dilakukan beberapa kali hingga bobot tetap, diperoleh hasil yaitu $11,5 \%$. Pada penetapan kadar sari yang larut dalam air kloroform, metode yang digunakan yaitu gravimetri. Setelah dimaserasi sampel 
tersebut disaring dan diuapkan diatas penangas air hingga kering dan dipanaskan dalam oven dengan suhu $105^{\circ} \mathrm{C}$ hingga bobot konstan. Persen kadar sari yang larut dalam air kloroform diperoleh yaitu $9,4 \%$.

Pada penetapan kadar sari yang larut dalam ethanol metode yang digunakan sama seperti pada penetapan kadar sari yang larut dalam air yaitu metode gravimetri. Pelarut yang digunakan untuk larutan penyari yaitu etanol 95\%. Kemudian diuapkan di atas penangas air hingga kering dan dipanaskan di dalam oven dengan suhu $105^{\circ} \mathrm{C}$ hingga bobot konstan. Kadar sari yang larut dalam etanol diperoleh hasil yaitu 4,8\%.

\section{Ekstraksi Sampel Daun Kapuk}

Ekstraksi daun kapuk pada penelitian ini menggunakan metode maserasi. Maserasi dilakukan untuk mendapatkan ekstrak tanaman yang akan dijadikan sebagai bahan uji. Keuntungan menggunakan metode maserasi adalah alatnya sederhana, biaya yang diperlukan relatif sedikit, tanpa pemanasan sehingga gugusgugus yang tidak stabil tidak akan rusak atau menguap karena berlangsung pada kondisi yang dingin.

Pada pengujian alkaloid, tanin, steroid dan terpenoid yang digunakan adalah ekstrak kental dari daun kapuk. Sedangkan untuk uji flavonoid dan saponin digunakan ekstrak cairnya. Sebelum dilakukan maserasi, simplisia daun kapuk dikeringkan terlebih dahulu, kemudian dirajang kecil-kecil. Ciri-ciri waktu pengeringan yang telah selesai yaitu apabila bagian daun kapuk ini sudah dapat dipatahkan dengan mudah. Sedangkan tujuan simplisia dirajang kecil-kecil untuk memperluas luas permukaan dari simplisia, sehingga lebih mudah menarik zat aktif di dalamnya.

Pada saat proses perendaman simplisia, akan terjadi proses dimana pelarut akan masuk menembus dinding sel dan masuk ke dalam rongga sel yang mengandung zat aktif yang kemudian akan larut di dalam pelarut ini dan membawa keluar bersama larutan tersebut karena adanya perbedaan tekanan di dalam dan di luar sel. Proses ini akan terus berlangsung hingga terjadi keseimbangan konsentrasi larutan di dalam dan di luar sel. Pada proses maserasi, 5 gram simplisia daun kapuk direndam dalam pelarut selama 24 jam dan dilakukan penggantian pelarut setiap 24 jam sekali sebanyak 3 (tiga) kali pengulangan.

Pelarut yang digunakan untuk merendam simplisia adalah ethanol $95 \%$. Ethanol dipertimbangkan sebagai penyari, karena bersifat universal, kapang dan kuman lebih sulit tumbuh dalam ethanol $20 \%$ ke atas, tidak netral, absorbsinya baik, dan juga etanol dapat bercampur dengan air pada segala perbandingan dan panas yang diperlukan untuk pemekatan jauh lebih sedikit. Ethanol dapat melarutkan alkaloid, minyak menguap, glikosida, kurkumin, antrakinon, flavonoid dan steroid. Ekstrak cair yang didapatkan dari hasil maserasi ini berwarna hijau jernih.

Setelah didapatkan ekstrak cair hasil maserasi, ekstrak cair tersebut diambil untuk dibuat menjadi ekstrak kental dengan menyisahkan $5 \mathrm{ml}$ ekstrak cair untuk identifikasi flavonoid dan saponin. Ekstrak kental ini dibuat dengan cara menguapkan ekstrak cair di atas waterbath atau penangas air hingga ekstrak cair tersebut menjadi kental. Tujuannya agar ethanol 
yang digunakan sebagai pelarut zat-zat aktif pada saat maserasi dapat menguap dan yang tersisa hanya murni ekstrak dari daun kapuk tersebut. Ekstrak kental ini berwarna coklat kehitaman.

\section{Uji Fitokimia}

Dari hasil proses maserasi dengan ethanol $95 \%$ selama 3 hari diperoleh ekstrak kental dan ektrak cair, selanjutnya dilakukan proses identifikasi fitokimia pada masing-masing ekstrak dengan menggunakan pereaksi yang sesuai dan memperoleh hasil yang dapat dilihat pada tabel 1 .

a. Identifikasi Tanin

Pada identifikasi tanin yaitu dengan menimbang ekstrak kental sebanyak 0,511 gram ditambah dengan $50 \mathrm{ml}$ air kemudian dipanaskan di atas penangas air selama 30 menit sambil diaduk hingga mendidih. Diamkan beberapa saat lalu saring, kemudian diambil filtrat sebanyak 5 tetes dan dimasukkan ke dalam tabung reaksi. Larutan kemudian direaksikan dengan 2 tetes larutan $\mathrm{FeCl}_{3}$, dan hasilnya terbentuk larutan yang berwarna coklat kehitaman. Pada uji menggunakan albumin dalam hal ini diganti dengan putih telur tidak terdapat adanya endapan pada larutan uji. Ini menandakan bahwa sampel negatif mengandung tanin.

Tanin membentuk senyawa larut dalam air berwarna hitam kehijauan atau biru gelap. Dipercayai bahwa tanin dapat memberikan perlindungan terhadap serangan mikroba (Nahar Luftun dan Sarker.D. Satyajit. 2009).

b. Identifikasi Alkaloid

Pada identifikasi alkaloid dengan menimbang ekstrak kental sebanyak 0,514 gram, kemudian ditambahkan dengan $1 \mathrm{ml}$ asam klorida dan $9 \mathrm{ml}$ air suling. Panaskan selama 2 menit, lalu dinginkan dan disaring. Hasil saringan kemudian diambil sebanyak 2 tetes ke dalam tabung reaksi dan diuji dengan pereaksi Dragendroff, Meyer dan Bouchardat untuk masing-masing bahan uji sebanyak 3 tetes.

Bahan uji dengan penambahan pereaksi Dragendroff terbentuk endapan merah jingga yang artinya positif mengandung alkaloid. Pada bahan uji dengan penambahan pereaksi Meyer tidak terbentuk endapan putih kekuningan yang berarti hasilnya negatif mengandung alkaloid. Dan pada penetesan pereaksi Bouchardat terbentuk endapan coklat yang menyatakan hasilnya positif mengandung alkaloid. Jadi, identifikasi alkaloid pada tumbuhan daun kapuk dinyatakan positif mengandung alkaloid. Sejumlah alkaloid alami dan turunannya telah dikembangkan sebagai obat untuk mengobati berbagai macam penyakit seperti morfin, reserpin dan taxol (Gunawan, Didik dan Mulyani, Sri. 2004).

c. Identifikasi Saponin

Pada identifikasi saponin dengan mengambil ekstrak cair sampel sebanyak $1 \mathrm{ml}$ dan diencerkan dengan aquadest sebanyak $10 \mathrm{ml}$, lalu dikocok kuat-kuat selama 10 detik, yang kemudian terbentuk buih yang mantap selama tidak kurang dari 10 menit. Lalu pada penambahan 1 tetes asam klorida $2 \mathrm{~N}$, buih tidak hilang, yang artinya sampel ini positif mengandung saponin. Saponin memiliki kegunaan dalam pengobatan, terutama karena sifatnya yang mempengaruhi absorpsi zat aktif secara farmakologi (Gunawan, Didik dan Mulyani, Sri. 2004).

d. Identifikasi Flavonoid

Pada identifikasi flavonoid sebanyak $1 \mathrm{ml}$ ekstrak cair ditambahkan dengan 1,012 gram serbuk Mg (Magnesium) dan beberapa tetes (1-2 
tetes) HCL pekat. Jika terjadi warna merah jingga sampai merah ungu, menunjukkan adanya flavonoid. Hasil yang diperoleh tidak terdapatnya warna merah jingga pada daun kapuk sehingga diperoleh hasil negatif untuk identifikasi flavonoid. e. Identifikasi Steroid dan Terpenoid

Pada identifikasi steroid dan terpenoid dengan menimbang ekstrak kental sebanyak 0,501 gram, lalu ditambahkan dengan 2 tetes Asam Asetat Anhidrat dan 1 tetes asam sulfat pekat. Apabila larutan menjadi berwarna merah untuk pertama kali dan kemudian berubah menjadi biru dan hijau maka menunjukkan sampel positif mengandung steroid dan terpenoid. Namun pada penelitian kali ini, hasilnya larutan menjadi berwarna cokelat kehitaman. Ini menandakan bahwa hasil yang diperoleh sampel daun kapuk mengandung steroid dan terpenoid. Jadi pada daun kapuk ini terkandung golongan senyawa yang berguna bagi tubuh seperti saponin, alkaloid, steroid dan terpenoid. Saponin memliki kegunaan dalam pengobatan salah satunya dapat meningkatkan aktivitas epitel yang bersilia, yaitu suatu peristiwa yang merangsang timbulnya batuk untuk mengeluarkan dahak (Gunawan, Didik dan Mulyani, Sri. 2004). Alkaloid banyak digunakan secara luas dalam bidang pengobatan, dikarenakan memiliki kegiatan fisiologi yang menonjol (Harborne.J.B, 1987). Dengan adanya kandungan senyawa alam seperti alkaloid, saponin, steroid dan terpenoid maka daun kapuk dapat digunakan sebagai obat tradisional.

KESIMPULAN DAN SARAN

\section{Kesimpulan}

Berdasarkan penelitian yang telah
dilakukan terhadap daun kapuk, dapat

disimpulkan bahwa pada skrining fitokimia yang telah dilakukan :

1. Daun kapuk positif mengandung golongan senyawa alkaloid, saponin steroid dan terpenoid.

2. Pada daun kapuk tidak ditemukan adanya golongan senyawa tanin, dan flavonoid.

3. Daun kapuk dapat digunakan sebagai acuan awal untuk pengobatan karena mengandung senyawa saponin, alkaloid steroid dan terpenoid yang memiliki efek terapi bagi tubuh. Salah satunya dapat digunakan sebagai analgesik dan saponin dapat digunakan sebagai antiseptik.

\section{Saran}

1. Pada penelitian selanjutnya dapat dilakukan dengan meneliti senyawa-senyawa lain selain yang sudah diteliti di atas.

2. Untuk identifikasi fitokimia lainnya juga dapat dilakukan dengan metode yang lain seperti menggunakan kromatografi.

3. Disarankan penelitian lebih lanjut dapat meneliti tentang kadar total senyawa alkaloid, saponin, steroid dan terpenoid yang terdapat di dalam daun kapuk.

\section{DAFTAR PUSTAKA}

Agoes, Goeswin.2007. Seri Farmasi Industri, Teknologi Bahan Alam. Bandung: penerbit ITB, halaman 8, 21.

Anonim. 1979. Farmakope Indonesia Ed IV. Jakarta. Departemen Kesehatan Republik Indonesia, halaman 7.

Anonim. 1979. Farmakope Indonesia Edisi III. Jakarta : Departemen Kesehatan Republik Indonesia, halaman 9.

Anonim. 1989. Materia Medika Indonesia Jilid V. Jakarta. Departemen Kesehatan Republik Indonesia, halaman XV. 
Anonim. Alkaloid. Situs Web Wikipedia [Di akses 30 April 2012]

Anonim. Bahan Baku Obat Tradisional dalam Obat Tradisional.Com [Di akses 29 April 2012]

Anonim. Fitokimia. Situs Web Wikipedia [Di akes 29 April 2012]

Anonim. Kelebihan dan Kelemahan Obat tradisional dalam Obat Tradisional. Com [Di akes 28 April 2012]

Bastian Lumbanraja, Linnon. 2009. Identifikasi Fitokimia dan Uji Efek Antiinflamasi Ekstrak Etanol Daun Tempuyung (Sonchus arvensis L) Terhadap Radang Pada Tikus. Fakultas Farmasi : Universitas Sumatera Utara
Departemen Kesehatan. 2009. Undang-Undang Republik Indonesia Nomor 23 Tahun 1992 tentang Kesehatan.

Departemen Kesehatan. 2009. Undang-Undang Republik Indonesia Nomor 36 Tahun 2009 tentang Kesehatan.

Gunawan, Didik dan Mulyani, Sri. 2004. Ilmu Obat Alam (Farmakognosi) jilid I. Jakarta. Penebar Swadaya, halaman 87,88.

Hanief, Moh. 2005. IImu Meracik Obat. Yogyakarta. Gadjah Mada University Press.

Heyne, K. 1987,Tumbuhan Berguna Indonesia (Terjemahan). Badan Penelitian dan Pengembangan Kehutanan, Departemen Kehutanan, Jakarta

Tabel Uji Fitokimia

\begin{tabular}{|c|c|c|c|c|c|}
\hline No & $\begin{array}{l}\text { Senyawa } \\
\text { yang diuji }\end{array}$ & $\begin{array}{c}\text { Pereaksi yang } \\
\text { digunakan }\end{array}$ & $\begin{array}{l}\text { Hasil Standar sesuai } \\
\text { (Materia Medika } \\
\text { Indonesia }\end{array}$ & Hasil Pengamatan & Ket. \\
\hline 1. & Tanin & $\begin{array}{l}\mathrm{FeCl}_{3} \text { ditambah } \\
\text { albumin (putih telur) }\end{array}$ & $\begin{array}{lrr}\text { Berwarna } & \text { hitam } \\
\text { kehijauan atau } & \text { biru } \\
\text { gelap } & & \end{array}$ & $\begin{array}{l}\text { Larutan berwarna hijau } \\
\text { kehitaman dan terdapat } \\
\text { adanya endapan }\end{array}$ & Negatif \\
\hline \multirow[t]{3}{*}{2.} & \multirow[t]{3}{*}{ Alkaloid } & Dragendroff & $\begin{array}{l}\text { Terdapat adanya } \\
\text { endapan merah bata }\end{array}$ & Terbentuk endapan merah & Positif \\
\hline & & Meyer & $\begin{array}{l}\text { Endapan menggumpal } \\
\text { berwarna putih atau } \\
\text { kuning }\end{array}$ & Terbentuk endapan putih & Negatif \\
\hline & & Bouchardat & $\begin{array}{l}\text { Endapan cokelat } \\
\text { sampai hitam }\end{array}$ & Terbentuk endapan cokelat & Positif \\
\hline 3. & Saponin & HCL $2 \mathrm{~N}$ & $\begin{array}{l}\text { Terbentuk buih mantap } \\
\text { selama tidak kurang } \\
\text { dari } 10 \text { menit }+\mathrm{HCL} 2 \mathrm{~N} \\
\text { Buih tidak hilang }\end{array}$ & Buih tidak hilang & Positif \\
\hline 4. & Flavonoid & $\begin{array}{c}\text { Serbuk Magnesium } \\
\text { dan HCL }\end{array}$ & $\begin{array}{l}\text { Jika terjadi warna } \\
\text { merah jingga sampai } \\
\text { merah } \\
\text { ungu,menunjukkan } \\
\text { adanya flavonoid. }\end{array}$ & $\begin{array}{l}\text { Warna menjadi bening, tidak } \\
\text { menimbulkan adanya warna } \\
\text { jingga sampai ungu merah }\end{array}$ & Negatif \\
\hline 5. & $\begin{array}{c}\text { Steroid } \\
\text { dan } \\
\text { Terpenoid }\end{array}$ & $\begin{array}{l}\text { Asam Asetat Anhidrat } \\
\text { dan Asam Sulfat Pekat }\end{array}$ & $\begin{array}{l}\text { Tidak terbentuk larutan } \\
\text { berwarna merah yang } \\
\text { kemudian menjadi biru } \\
\text { dan hijau. }\end{array}$ & $\begin{array}{l}\text { Terbentuk warna larutan } \\
\text { cokelat kehitaman }\end{array}$ & Positif \\
\hline
\end{tabular}

